\title{
ANALISIS FAKTOR YANG MEMENGARUHI PARTISIPASI PRIA DALAM KELUARGA BERENCANA DI DESA CELAWAN KECAMATAN PANTAI CERMIN KABUPATEN SERDANG BEDAGAI
}

\author{
Factor Analysis of Affecting Men's Participation in Family Planning in Villages \\ Against Substances of Cermin Beach District of Serdang Bedagai
}

\author{
Tisnilawati \\ Dosen Akademi Kebidanan Indah Medan \\ Email : akbidindahmedan@yahoo.co.id
}

\begin{abstract}
Abstrak
Partisipasi pria dalam KB di Indonesia sampai saat ini masih sangat rendah. Pencapaian program akseptor kondom aktif di Provinsi Sumatera Utara tahun 2011 sebesar 18,7\% dan akseptor Metode Operasi Pria (MOP) aktif 53,2\%. Pencapaian peserta KB kondom di Kabupaten Serdang Bedagai, yaitu 13,1\% sedangkan pencapaian peserta MOP 55,2\%. Desa Celawan merupakan salah satu desa di Kecamatan Pantai Cermin Kabupaten Serdang Bedagai yang memiliki partisipasi pria dalam KB cukup tinggi, yaitu kondom sebanyak $5,2 \%$, dan MOP sebanyak 1,0\%.

Penelitian ini bertujuan untuk mereduksi faktor-faktor yang memengaruhi partisipasi pria dalam keluarga berencana, meliputi faktor predisposisi (pengetahuan dan sikap), pendukung (akses pelayanan dan fasilitas) dan penguat (dukungan istri, dukungan keluarga dan dukungan teman) di Desa Celawan Kecamatan Pantai Cermin Kabupaten Serdang Bedagai. Jenis penelitian survei dengan pendekatan cross sectional. Penelitian ini dilaksanakan bulan Agustus sampai dengan Nopember 2014. Populasi adalah seluruh suami PUS yang berpartisipasi dalam KB berjumlah 60 orang dan seluruh populasi dijadikan sampel. Data diperoleh dengan wawancara menggunakan kuesioner, dianalisis dengan analisis faktor metode eksploratori.

Hasil penelitian menunjukkan bahwa secara statistik analisis faktor yang memengaruhi partisipasi pria dalam $\mathrm{KB}$, yaitu; (1) faktor fasilitas meliputi; fasilitas pelaksanaan $\mathrm{KB}$, konsultasi dan bimbingan dari petugas $\mathrm{KB}$, ketersediaan transportasi rujukan, (2) faktor partisipasi meliputi; motivasi, pemahaman tentang jenis kontrasepsi, dukungan terhadap program KB, dan pemahaman terhadap organ reproduksi, (3) faktor respon terhadap metode KB meliputi; respon terhadap alat KB, efek samping, biaya KB jangka pendek dan panjang, (4) faktor lokasi meliputi; kemudahan menuju fasilitas kesehatan, keberadaan petugas, kemudahan mendapatkan informasi, dan ketersediaan alat $\mathrm{KB}$, dan (5) faktor pendukung meliputi dukungan istri dalam memilih alat KB, dukungan menjadi kader KB, dan dukungan terhadap metode KB yang digunakan. Kelima faktor tersebut memiliki kekuatan sebesar 69,5\% mampu menjelaskan pengaruh partisipasi pria dalam keluarga berencana.
\end{abstract}

Kata kunci : Analisis Faktor, Partisipasi Pria, Keluarga Berencana

\begin{abstract}
Up to now, male participation in Family Planning in Indonesia has been very low. The achievement of active condom acceptor program in North Sumatera Province in 201I was 18.7\% and active acceptors of MOP (Male Operation Method) were 53.2\%. The achievement of condom Family Planning acceptors in Serdang Bedagai District was I3.1\%, while the achievement of MOP acceptors was 55.2\%. Celawan Village is one of the villages in Pantai Cermin Subdistrict, Serdang Bedagai District, which has high male participation in Family Planning: condom was 5.5\% and MOP was $1.0 \%$.

The objective of the research was to reduce some factors which influenced male participation in Family Planning program which included predisposition factors (knowledge and attitude), support (access to service and facilities), and motivation (wife's support, family support, and peer group support) at Celawan Village, Pantai Cermin Subdistrict, Serdang Bedagai District. The research was survey with cross sectional design. It was conducted from August to November, 2014. The population was 60 husbands of fertile age couples who participated in Family Planning, and all of them were used as the samples. The data were collected by conducting interviews with questionnaires and analyzed by using exploratory method factor analysis.

The result showed that statistically the factors that influenced the participation of male in family Planning, were (1) facility factors included family planning facilities, consultation and guidance of family planning officers, the availability of referral transport, (2) participation factors included motivation, understanding of the types of contraception, support for family planning programs, and understanding of the reproductive organs, (3)response factors included access to family planning methods, side effects, cost of short and long term family planning, (4) the location factors included ease to the health facility, the presence of officers, access to information, and the availability of contraceptives, and (5) supporting factors included wife
\end{abstract}


support, support for becoming family planning cadres in choosing family planning methods. All five of these factors has the power of $69,5 \%$ able to explain the influence of the participation of male in family planning.

Keywords: Factor Analysis, Male Participation, Family Planning

\section{PENDAHULUAN}

Program keluarga berencana merupakan salah satu program pem-bangunan nasional yang sangat penting dalam rangka mewujudkan keluarga Indonesia yang sejahtera. Peran program Keluarga Berencana (KB) sangat besar pengaruhnya terhadap kesehatan reproduksi seseorang, baik itu untuk kesehatan reproduksi wanita maupun kesehatan reproduksi pria.

Program KB juga berperan bagi kesehatan reproduksi suami antara lain untuk mencegah terkena Penyakit Menular Seksual (PMS) dan penyakit kelamin lain yang diakibatkan oleh tidak menggunakan alat kontrasepsi (kondom) ketika melakukan hubungan seksual dengan istrinya yang terkena PMS. Berdasarkan Peraturan Presiden No. 7 tahun 2004 tentang Rencana Pembangunan Jangka Menengah (RPJM) ditetapkan bahwa peserta KB pria sebesar 4,5\%, namun kenyataannya partisipasi pria dalam KB masih rendah.

Perkembangan partisipasi pria dalam KB khususnya dalam penggunaan kontrasepsi selama kurun waktu 12 tahun terakhir belum memperlihatkan kenaikan yang berarti, yaitu hanya $0,2 \%$. Hal ini dapat dilihat dari angka pencapaian peningkatan partisipasi pria tahun 1991 sebesar 0,8\% (SDKI 1991), pada tahun 2003 sebesar 1,3\% (SDKI 2002-2003), pada tahun 2007 sebesar 1,5\%, sedangkan pada tahun 2012 kondom $0,7 \%$ sterilisasi pria $0,1 \%$ (SDKI, 2012).

Dalam keputusan MDGs (Millenium Development Goals) men-dorong kesetaraan gender dan pem-berdayaan perempuan, dan RPJMN 2010-2014, meningkatkan kesertaan KB Pria tahun 2010 sebesar 3,6 \%, tahun 2011 sebesar 4\%, tahun 2012 sebesar 4,3\%, tahun 2013 sebesar 4,6\% dan tahun 2014 sebesar 5\%. Menurut BkkbN (2011) tingginya angka kelahiran di Indonesia telah menyedot anggaran yang sangat besar dalam memenuhi kebutuhan rakyat seperti pendidikan, kesehatan, dan biaya subsidi bagi rakyat miskin. Pertumbuhan penduduk Indonesia mengalami peningkatan yang sangat tajam dari perkiraan 1,14 persen pada tahun 2010 menjadi 1,49 persen tahun 2014, hal ini diakibatkan tingginya angka kelahiran secara nasional mencapai 2,6 persen/wanita subur, Sumatera Utara mencapai 3,8 persen/wanita subur.

Sumatera Utara dihadapkan pada tantangan besar dalam Pembangunan Kependudukan dan Keluarga Berencana, yaitu tantangan komitmen politis dan dukungan operasional pemerintah nasional, provinsi, dan kabupaten/kota yang mengalami penurunan. Terbukti struktur dan penggerak program KB di wilayah pedesaan dan terjauh sangat memprihatinkan dan masih kurangnya pengetahuan, pemahaman dan lemahnya pengendalian pemakaian kontrasepsi. Maka pendekatan pembangunan kependudukan tidak lagi berorientasi kepada kepadatan wilayah, tetapi dengan pendekatan kepadatan jiwa dalam keluarga (BkkbN, 2011).

Prevalensi pemakaian kon-trasepsi di Indonesia masih rendah dan bervariasi antar propinsi, status ekonomi, tingkat pendidikan, dan desa-kota. Bila dilihat hasil SDK1 20022003 dan 2007, prevalensi pemakaian kontrasepsi CPR cara modern tidak menunjukkan peningkatan yang berarti, yaitu $56,7 \%$ menjadi $57,4 \%$, dan menurun menjadi $55,85 \%$ pada tahun 2010 serta tahun 2012 meningkat menjadi 57,9\% (SDKI, 2012). Untuk jenis alat KB yang digunakan secara nasional, menurut SDKI 2007 didominasi dengan cara suntik $32,3 \%$, selanjutnya pil $12,8 \%$. Sedangkan menurut SDKI 2012, terjadi peningkatan, yaitu cara suntik 42,7\% dan cara pil $15,6 \%$. Jumlah peserta KB pria diberbagai negara bervariasi yaitu: Korea 27\%, Sri Lanka 26\%, Filipina $24 \%$, Bangladesh $18 \%$, Nepal 18\%, Malaysia $16,8 \%$, China $11 \%$, Thailand 9\%, Pakistan 9\%, Indonesia 1,3\% (BkkbN, 2012a).

Kondom merupakan metode kontrasepsi kedua yang paling umum di Eropa, mendekati 30 persen dari penggunaan kontrasepsi modern. Mereka mencapai kurang dari 20 persen dari penggunaan kontrasepsi di setiap wilayah lainnya. Data prevalensi kondom di Afrika (8\%), Asia (12\%), Eropa (28\%), Amerika latin (14\%), Amerika Utara (18\%), dan di Osenia (19\%) (Earth Policy Institute, 2012).

Menurut SDKI 2012, pengetahuan mengenai pembatasan kelahiran dan keluarga berencana $(\mathrm{KB})$ merupakan salah satu aspek penting ke arah pemahaman tentang berbagai alat/cara kontrasepsi yang tersedia. Selanjutnya, 
pengetahuan tersebut akan berpengaruh kepada pemakaian alat/cara kontrasepsi yang tepat dan efektif. Pengetahuan responden mengenai metode kontrasepsi diperoleh dengan cara menanyakan semua jenis alat atau cara kontrasepsi yang pernah didengar untuk menunda atau menghindari terjadinya kehamilan dan kelahiran. pemakaian alat $\mathrm{KB}$ dikalangan pria yang berstatus kawin menunjukkan bahwa pemakaian alat $\mathrm{KB}$ pria masih sangat terbatas. Metode yang paling banyak mereka gunakan adalah senggama terputus $(2,3 \%)$ pantang berkala $(1,3 \%)$, kondom $(1,8 \%)$ dan sterilisasi pria $(0,2 \%)$ (Kemenkes RI, 2012).

Berdasarkan hasil Riskesdas tahun 2013, ditemukan bahwa akseptor keluarga berencana kondom di perkotaan $(1,1 \%)$ dan akseptor keluarga berencana kondom diperdesaan $(0,3 \%)$. Dengan kelompok umur yang terbanyak akseptor keluarga berencana kondom yaitu kelompok umur 30-39 tahun. Latar belakang pendidikan yang terbanyak akseptor keluarga berencana kondom yaitu tamat perguruan tinggi $(2,4 \%)$ dengan latar belakang pekerjaan pegawai $(1,9 \%)$, akseptor keluarga berencana MOP di perkotaan dan perdesaan $(0,1 \%)$. Dengan kelompok umur yang terbanyak akseptor keluarga berencana MOP yaitu kelompok umur 40-49 tahun (0,2\%). Latar belakang pendidikan yang terbanyak akseptor keluarga berencana MOP yaitu tamat SD $(0,2 \%)$ dengan latar belakang pekerjaan pegawai dan petani/ne-layan/buruh $(0,2 \%)$ (Kemenkes RI, 2013)

Pencapaian program KB nasional Propinsi Sumatera Utara pada tahun 2011, yaitu pencapaian akseptor kondom aktif sebesar $(18,71 \%)$, pencapaian akseptor MOP aktif $(53,21 \%)$. Pencapaian peserta keluarga berencana kondom di Kabupaten Serdang Bedagai yaitu $13,1 \%$ sedangkan pencapaian peserta keluarga berencana MOP 55,2\%. (BkkbN, 2011).

Dalam rangka menyukseskan visi dan misi program $\mathrm{KB}$, salah satu masalah yang menonjol adalah rendahnya partisipasi pria dalam pelaksanaan program KB.Faktor-faktor yang menyebabkan rendahnya kesertaan $\mathrm{KB}$ pria antara lain: (1) Pelaksanaan program KB masa lalu yang cenderung mengarahkan sasarannya lebih pada perempuan. (2) Terbatasnya informasi yang sampai kepada laki-laki tentang KB dan kesehatan reproduksi yang berakibat kepada terbatasnya pengetahuan kaum laki-laki. (3) Faktor sosial budaya yang menganggap $\mathrm{KB}$ merupakan urusan perempuan. (4) Masih terbatasnya jumlah pemberi pelayanan yang berminat kepada pelayanan untuk laki-laki, baik $\mathrm{KB}$ maupun kesehatan reproduksi. (5) Terbatasnya jenis metode kontrasepsi pria membuat laki-laki tidak mau menjadi peserta KB. (6) Dominannya suami dalam pengambilan keputusan keluarga (Parwieningrum, 2009).

Banyak faktor yang menyebabkan rendahnya partisipasi pria dalam keluarga berencana yang dilihat dari berbagai aspek, yaitu dari sisi klien pria itu sendiri (pengetahuan, sikap dan praktek serta kebutuhan yang ia inginkan), faktor lingkungan yaitu sosial budaya, dukungan istri, masyarakat (tokoh masyarakat) dan keluarga, keterbatasan informasi dari tenaga kesehatan dan aksesabilitas terhadap pelayanan keluarga berencana pria, keterbatasan jenis kontrasepsi pria disertai masih adanya persepsi di masyarakat mengenai keluarga berencana pria $(\mathrm{BkkbN}$, 2010).

Permasalahan yang dihadapi saat ini adalah masih banyaknya para pria yang kurang perduli terhadap kesertaan keluarga berencana, keputusan untuk menggunakan kontrasepsi diserahkan sepenuhnya kepada istri dan bukan keputusan mereka bersama. Disisi lain, pihak perempuan seringkali keputusannya dalam pemakaian kontrasepsi justru kurang mendukung partisipasi pria, karena perempuan lebih banyak mengalah. Selain itu, masih ada hambatan kultural dalam masyarakat yang menganggap keluarga berencana dan kesehatan reproduksi. kesehatan ibu dan anak adalah urusan perempuan yang hamil dan melahirkan, selain itu kebiasaan perernpuan untuk menerima perilaku sosial tersebut sebagai hal yang wajar, pilihan kontrasepsi pria hanya dua, yaitu: kondom dan vasektomi, serta kurangnya dukungan dari para tokoh masyarakat/agama/adat yang seharusnya menjadi contoh bagi masyarakat setempat (BkkbN, 2009a).

Menurut Green (1980) dalam Notoatmodjo (2012) determinan masalah kesehatan dibedakan atas dua faktor, yaitu behavioral factor (faktor perilaku) dan non behavioral factor (faktor non perilaku). Faktor 
perilaku kesehatan dipengaruhi oleh tiga faktor utama, yaitu; (a) faktor predisposing atau predisposisi, merupakan faktor yang mempermudah atau mempredisposisi terjadinya perilaku seseorang antara lain pengetahuan, sikap, nilai, kepercayaan, pendidikan, dan sosial ekonomi, (b) faktor enabling atau pendorong, merupakan faktor yang memungkinkan atau yang memfasilitasi prilaku atau tindakan meliputi; lingkungan fisik dan fasilitas/sarana pelayanan kesehatan untuk terjadinya prilaku kesehatan, dan (c) faktor reinforcing atau penguat merupakan faktor yang mendorong atau memperkuat terjadinya prilaku meliputi; sikap dan perilaku petugas kesehatan atau petugas lain serta dukungan keluarga. Partisipasi pria dalam keluarga berencana dapat dipengaruhi oleh ketiga faktor (predisposisi, pendorong, dan penguat) tersebut.

Berdasarkan Data Badan Pemberdayaan Perempuan, Anak dan Keluarga Berencana Kabupaten Serdang Bedagai tahun 2013, jumlah Pasangan Usia Subur (PUS) adalah sebanyak 146.616, yang memakai alat kontrasepsi pria metode kondom sebanyak 4,9\%, dan memakai alat kontrasepsi Metode Operasi Pria (MOP) sebanyak 0,6\%. Kecamatan Pantai Cermin merupakan salah satu kecamatan yang berada di Kabupaten Serdang Bedagai. Salah satu desa di Kecamatan Pantai Cermin adalah Desa Celawan. Berdasarakan hasil survei pendahuluan ditemukan partisipasi pria dalam KB didesa ini cukup tinggi diantara beberapa desa dikecamatan Pantai Cermin dengan jumlah PUS sebanyak 954, yang memakai alat kontrasepsi pria metode kondom sebanyak $5,2 \%$, dan memakai alat kontrasepsi MOP sebanyak $1,0 \%$.

\section{PERMASALAHAN}

Berdasarkan latar belakang di atas, maka sebagai permasalahan dalam penelitian ini adalah bagaimana aplikasi analisis faktor dengan metode eksploratori dalam mereduksi faktor-faktor yang memengaruhi partisipasi pria dalam keluarga berencana meliputi faktor, predisposisi (pengetahuan dan sikap), pendukung (akses pelayanan dan fasilitas) dan penguat (dukungan istri, dukungan keluarga dan dukungan teman) di Desa Celawan Kecamatan Pantai Cermin Kabupaten Serdang Bedagai?.

\section{TUJUAN PENELITIAN}

Mereduksi faktor-faktor yang memengaruhi partisipasi pria dalam keluarga berencana meliputi faktor predisposisi (pengetahuan dan sikap), pendukung (akses pelayanan dan fasilitas) dan penguat (dukungan istri, dukungan keluarga dan dukungan teman) di Desa Celawan Kecamatan Pantai Cermin Kabupaten Serdang Bedagai.

\section{MANFAAT PENELITIAN}

1. Penelitian ini diharapkan bisa memberikan masukan bagi petugas kesehatan dan KB dalam rangka meningkatkan cakupan dan kualitas pelayanan $\mathrm{KB}$ serta pengambilan kebijakan untuk program peningkatan partisipasi pria dalam KB.

2. Bagi peneliti selanjutnya, hasil penelitian ini diharapkan dapat dipakai sebagai bahan referensi dalam hal yang berkaitan dengan faktor yang memengaruhi partisipasi pria dalam keluarga berencana.

\section{METODE PENELITIAN}

Penelitian ini menggunakan metode survei, dengan pendekatan Cross sectional dimana proses pengambilan data dilakukan dalam waktu bersamaan. Penelitian ini bertujuan untuk mereduksi data dan menginterpretasikannya sebagai suatu variabel baru yang berupa variabel bentukan dari analisis faktor-faktor yang memengaruhi partisipasi pria dalam keluarga berencana. Populasi dalam penelitian ini adalah seluruh suami PUS yang ikut berpartisipasi dalam ber KB yang bertempat tinggal di Desa Celawan Kecamatan Pantai Cermin Kabupaten Serdang Bedagai, yaitu sebanyak 60 orang dan seluruh populasi dijadikan sampel.

Data yang dikumpulkan berupa data primer diperoleh melalui wawancara langsung dengan responden dan sekunder diperoleh di Badan Pemberdayaan Perempuan, Anak dan Keluarga Berencana Kabupaten Serdang Bedagai. Data dianalisis menggunakan analisis faktor eksploratori dengan tingkat kepercayaan $95 \%(\alpha=0,05)$.

\section{HASIL DAN PEMBAHASAN 1. Peserta KB}

Hasil penelitian menunjukkan bahwa peserta KB lebih banyak berumur 42-52 tahun, yaitu sebanyak 41 orang $(68,3 \%)$. Tingkat 
pendidikan lebih banyak tamat SLTA, yaitu sebanyak 26 orang $(43,3 \%)$. Berdasarkan pekerjaan lebih banyak petani, yaitu sebanyak 18 orang $(30,0 \%)$. Jumlah anak hidup lebih banyak pada kelompok 4-5 orang, yaitu sebanyak 33 orang $(55,0 \%)$ dan berdasarkan alat kontrasepsi yang digunakan lebih banyak menggunakan kondom, yaitu sebanyak 58 orang $(96,7 \%)$, selebihnya menggunakan MOP.

\section{Analisis Faktor yang Memengaruhi Partisipasi Pria dalam Keluarga Berencana}

Berdasarkan hasil penelitian diketahui bahwa faktor yang terbentuk meliputi ; (1) faktor fasilitas, (2) faktor partisipasi, (3) faktor respon, (4) faktor lokasi, dan (5) faktor pendukung.

\subsection{Faktor Fasilitas}

Hasil penelitian menunjukkan bahwa faktor fasilitas merupakan faktor yang terkuat sebagai pembentuk faktor partisipasi pria dalam KB. Fasilitas dalam hal ini adalah sarana pelayanan, yaitu menyediakan transportasi pergi dan pulang dari Puskesmas untuk berpartisipasi sebagai peserta KB pria mereka sangat senang, namun keadaan seperti ini tidak selamanya tersedia ketika dibutuhkan

Hasil penelitian ini didukung pendapat Donabedian (2005), menyatakan ada tiga pendekatan evaluasi (penilaian) mutu yang memengaruhi pemanfaatan pelayanan kesehatan, yaitu dari aspek struktur, proses dan outcome. Aspek-aspek dalam struktur dan proses melekat langsung dalam hubungan pasien dengan pemberi jasa pelayanan, yaitu aspek pelayanan kesehatan, aspek kompetensi petugas, aspek peralatan dan fasilitas serta jaminan kesehatan.

Berdasarkan analisis faktor sub variabel fasilitas merupakan salah satu sub variabel pembentuk faktor pendukung yang memengaruhi partisipasi pria dalam KB karena memiliki nilai eigen value 6,309>1. Hal ini memberikan makna bahwa sub variabel fasilitas mampu menjelaskan keragaman sebagai pembentuk asal faktor pendukung, semakin besar nilai eigen value sub variabel fasilitas semakin kuat mewakili keragaman variabel asal.

Hasil penelitian ini sejalan dengan teori Green dalam Notoatmodjo (2012) yang menyatakan bahwa fasilitas merupakan bagian dari faktor pendukung dalam membentuk perilaku seseorang dalam memanfaatkan sarana pelayanan kesehatan.

\subsection{Faktor Partisipasi}

Hasil penelitian menunjukkan bahwa sebagian besar responden menjawab salah dan tidak tahu pertanyaan tentang pengetahuan pria menjadi akseptor $\mathrm{KB}$, yaitu terkait dengan $\mathrm{KB}$ kondom dan metode MOP. Hal ini terkait dengan jawaban responden sebanyak $75 \%$ menjawab salah bahwa menjadi peserta KB dapat mengurangi kejantanan, sehingga memutuskan untuk berpartisipasi atau tidak dalam KB pria memakan waktu yang lama, karena responden belum mendapat informasi yang menyeluruh tentang $\mathrm{KB}$ MOP ini. Menurut responden pengetahuan tentang KB ini lebih banyak diperoleh dari mass media dibanding dengan petugas $\mathrm{KB}$.

Pengetahuan responden yang belum baik tentang $\mathrm{KB}$ ini terkait dengan karakteristik peserta KB pria yang memilki tingkat pendidikan yang rendah, yaitu sebanyak $50 \%$ responden tamat SD dan SLTP selebihnya tingkat pendidikan SLTA dan perguruan tinggi. Hal ini didukung hasil penelitian Ekayanthi (2005) menyimpulkan bahwa ada hubungan antara pengetahuan tentang metode kontrasepsi pria dengan persepsi PUS terhadap partisipasi pria dalam KB. Hal senada juga ditemukan dalam hasil penelitian Budisantoso dan Ekarini (2008) menyimpulkan bahwa partisipasi pria dalam KB masih rendah dipengaruhi oleh faktor pendidikan.

Berdasarkan analisis faktor sub variabel pengetahuan merupakan salah satu sub variabel pembentuk faktor predisposisi yang memengaruhi partisipasi pria dalam keluarga berencana karena memiliki nilai eigen value $4,083>1$. Hal ini memberikan makna bahwa sub variabel pengetahuan mampu menjelaskan keragaman sebagai pembentuk asal faktor predisposisi, semakin besar nilai eigen value sub variabel pengetahuan semakin kuat mewakili keragaman variabel asal.

Hasil penelitian ini didukung pendapat Suliyanto (2005) dan Hair (2010) yang mengungkapkan analisis faktor merupakan suatu teknik untuk menganalisis tentang saling ke-tergantungan dari beberapa variabel secara simultan dengan tujuan untuk menyederhanakan dari bentuk hubungan antara beberapa variabel 
yang diteliti menjadi sejumlah faktor yang lebih sedikit dari pada variabel yang diteliti.

\subsection{Faktor Respon}

Hasil penelitian menunjukkan bahwa sebagian besar responden belum sepenuhnya merespon atau menyikapi dengan baik program $\mathrm{KB}$ dan kesehatan reproduksi dan menganggap bahwa penggunaan kontrasepsi adalah urusan perempuan.

Berdasarkan analisis faktor sub variabel sikap (respon) merupakan salah satu sub variabel pembentuk faktor predisposisi yang memengaruhi partisipasi pria dalam KB karena memiliki nilai eigen value 3,171>1. Hal ini memberikan makna bahwa sub variabel sikap mampu menjelaskan keragaman sebagai pembentuk asal faktor predisposisi, semakin besar nilai eigen value sub variabel sikap semakin kuat mewakili keragaman variabel asal.

Sikap responden tentang partisipasi pria dalam KB didukung oleh hasil penelitian Widodo dkk, (2004) yang menyimpulkan bahwa sikap yang peduli terhadap masalah KB dan kesehatan reproduksi diyakini akan meningkatkan partisipasi pria dalam KB.

Hasil penelitian ini sejalan dengan teori Green dalam Notoatmodjo (2012) yang menyatakan bahwa sikap merupakan bagian dari faktor predisposisi yang sangat menentukan dalam membentuk perilaku seseorang.

\subsection{Faktor Lokasi}

Hasil penelitian menunjukkan bahwa akses menuju tempat atau lokasi pelayanan masih menjadi masalah bagi responden. Sebagian besar responden mengeluhkan masalah transportasi menuju Puskesmas tidak tersedia setiap saat dan belum sepenuhnya ada akses untuk memperoleh informasi dari petugas $\mathrm{KB}$.

Hasil penelitian Satyavada dan Adam (2000) di Nepal menyimpulkan bahwa perbaikan penyampaian informasi dalam pelayanan kontrasepsi dan penyediaan akses yang mudah secara signifikan dapat meningkatkan proporsi pemakaian kontrasepsi yang akhirnya akan memberikan pilihan terhadap pengaturan kelahiran dan jumlah keluarga. Meningkatkan penerimaan partisipasi pria dalam KB perlu dilakukan Komunikasi Informasi dan Edukasi (KIE) mengenai jenis metode kontrasepsi, tempat pelayanan $\mathrm{KB}$, dan biaya pelayanan KB dengan melibatkan kelompok atau paguyuban, petugas $\mathrm{KB}$, tokoh agama dan tokoh masyarakat.

Berdasarkan analisis faktor sub variabel akses lokasi pelayanan merupakan salah satu sub variabel pembentuk faktor pendukung yang memengaruhi partisipasi pria dalam KB karena memiliki nilai eigen value $1,999>1$. Hal ini memberikan makna bahwa sub variabel akses pelayanan sebagai pembentuk lokasi mampu menjelaskan keragaman sebagai pembentuk asal faktor pendukung, semakin besar nilai eigen value akses pelayanan semakin kuat mewakili keragaman variabel asal. Hasil penelitian ini sejalan dengan teori Green dalam Notoatmodjo (2012) yang menyatakan bahwa akses pelayanan sebagai pembentuk lokasi merupakan bagian dari faktor pendukung dalam membentuk perilaku seseorang.

\subsection{Faktor Pendukung}

Dukungan istri merupakan salah satu faktor pembentuk variabel penguat. Hal ini memberikan gambaran bahwa faktor dukungan istri merupakan salah satu faktor penentu tehadap partisipasi pria menjadi akseptor KB.

Berdasarkan analisis faktor sub variabel dukungan istri merupakan salah satu sub variabel pembentuk faktor penguat yang memengaruhi partisipasi pria dalam KB karena memiliki nilai eigen value $1,126>1$. Hal ini memberikan makna bahwa sub variabel dukungan istri mampu menjelaskan keragaman sebagai pembentuk asal faktor penguat, semakin besar nilai eigenvalue sub variabel dukungan istri semakin kuat mewakili keragaman variabel asal.

Hasil penelitian Suprihastuti (2002) menyimpulkan bahwa pengambilan keputusan bersama antara suami dan istri dapat meningkatkan penggunaan alat kontrasepsi pria. Hal ini didukung hasil temuan BkkbN (2009a) penentuan pengambilan keputusan dalam keluarga sebagian besar masih didominasi suami, maka pertanyaan partisipasi pria tidak hanya sebagai peserta KB saja tetapi juga mendukung istri dalam penggunaan kontrasepsi, pemberi pelayanan $\mathrm{KB}$ (motivator, promotor) dan merencanakan jumlah anak bersama pasangan.

Hasil penelitian ini sejalan dengan teori Green dalam Notoatmodjo (2012) yang 
menyatakan bahwa dukungan istri merupakan salah satu faktor penguat (reinforcing) yang membuat seseorang bertindak terhadap obyek tertentu. Namun faktor reinforcing dapat bersifat positif atau negatif tergantung sikap dan perilaku panutan.

\section{KESIMPULAN}

Berdasarkan hasil penelitian dan pembahasan diperoleh 5 (lima) faktor yang memengaruhi partisipasi pria dalam keluarga berencana, faktor-faktor tersebut adalah:

1. Faktor pertama merupakan faktor fasilitas meliputi; fasilitas pelaksanaan $\mathrm{KB}$, konsultasi dan bimbingan dari petugas $\mathrm{KB}$, ketersediaan transportasi rujukan dan ketersediaan transportasi pulang bagi akseptor KB.

2. Faktor kedua merupakan faktor partisipasi meliputi; motivasi akseptor KB, pemahaman tentang jenis kontrasepsi, dukungan terhadap program $\mathrm{KB}$, dan pemahaman terhadap organ reproduksi.

3. Faktor ketiga merupakan faktor respon terhadap suatu metode KB meliputi; respons terhadap alat $\mathrm{KB}$, respons terhadap efek samping metode $\mathrm{KB}$, respons terhadap biaya KB jangka pendek dan jangka panjang.

4. Faktor keempat merupakan faktor lokasi meliputi; kemudahan menuju fasilitas kesehatan, keberadaan petugas $\mathrm{KB}$, kemudahan mendapatkan informasi tentang $\mathrm{KB}$, dan ketersediaan alat $\mathrm{KB}$ pada fasilitas kesehatan.

5. Faktor kelima, merupakan faktor pendukung meliputi; dukungan istri dalam memilih alat $\mathrm{KB}$, dukungan istri menjadi kader $\mathrm{KB}$, dan dukungan istri terhadap metode $\mathrm{KB}$ yang digunakan

6. Kelima faktor tersebut sebesar $69,5 \%$ mampu menjelaskan pengaruh partisipasi pria dalam keluarga berencana.

\section{SARAN}

1. Puskesmas Kecamatan Pantai Cermin dan Dinas Kesehatan Kabupaten Serdang Bedagai untuk :

a. Mengupayakan peningkatan ke-lengkapan fasilitas pelaksanan KB pria dengan melengkapi sarana dan prasarana pelayanan kon-trasepsi mantap bersifat jangka panjang, aman, berkualitas. b. Mengupayakan peningkatan partisipasi pria melalui peningkat-an kemampuan dan keterampilan petugas memberikan penyuluhan atau KIE (Komunikasi Informasi Edukasi) untuk memotivasi pria menjadi peserta KB.

c. Mengupayakan peningkatan respon pria terhadap alat $\mathrm{KB}$ melalui pemberian penyuluhan atau KIE (Komunikasi Informasi Edukasi) dengan bahasa yang mudah dipahami oleh calon dan akseptor KB pria.

d. Mengupayakan peningkatan bantuan transportasi menuju lokasi pelayanan kesehatan dan memberikan kemudahan dalam mendapatkan informasi tentang $\mathrm{KB}$ bagi calon akseptor KB pria.

e. Mengupayakan keikutsertaan istri dalam memberikan informasi tentang alat, metode, jenis kontrasepsi yang hendak digunakan suami untuk ber-partisipasi dalam program KB.

2. Peserta KB Pria mengupayakan mempertahan kan keikutsertaan-nya, sehingga diharapkan mampu memotivasi calon akseptor yang belum terlibat secara aktif dalam program KB.

3. Istri berupaya meningkatkan dukungan kepada suami untuk terus berpartisipasi dalam program KB.

4. BkkbN perlu mengupayakan memperbaiki revitalisasi program KB dengan melibatkan stakeholders (pemangku kepenting- an) dibidang kependudukan dan KB, Bupati maupun Walikota dan semua pimpinan Satuan Kerja Perangkat daerah (SKPD) sebagai penggerak terdepan program KB.

\section{DAFTAR PUSTAKA}

BkkbN, 2009a. Kesetaraan dan Keadilan Gender dalam KB dan Kesehatan Reproduksi. Jakarta.

,2010. Peningkatan Partisipasi Pria. Jakarta.

,2011. Perkembangan Program

Keluarga Berencana Nasional Provinsi Sumatera Utara. Medan.

,2012a. Pelatihan Klinik Teknologi Kontrasepsi Terkini Propinsi Sumatera Utara. Medan. 
Donabedian, A. 2005. Aspects of Medical Care Administration Specifying Requirements for Health Care. Harvard University Press, Massachusetts, London.

Earth Policy Institute, 2012. Data Highlight : Growth in World Contraception Use Stalling ; 215 Milion Womens Needs Still Unmet.Http: www.earth policy.org/data highlights/ 2012/highlight26, diakses tanggal 17 Oktober 2012.

Ekarini, S., 2008. Analisis Faktor-Faktor yang berpengaruh terhadap Partisipasi Pria dalam Keluarga Berencana di Kecamatan Selo Kabupaten Semarang. Tesis. Program Pasca Sarjana Ilmu Kesehatan Masyarakat Universitas Diponegoro Semarang.

Ekayanthi, Ni Wayan Dian, 2005. Persepsi Pria Pasangan Usia Subur Terhadap Partisipasi Pria Dalam Program KB di Kecamatan Tabanan, Kab. Tabanan, Prop Bali, UGM, Yogyakarta.

Hair, J.F. et al. 2010. Multivariate Data Analysis: A Global Perspective, 7th Edition. New Jersey: Person Prentice Hall

Kemenkes, RI, 2012. Survei Demografi dan Kesehatan Indonesia 2012, Badan Kependudukan dan Keluarga Berencana Nasional. Kementerian Kesehatan RI, Jakarta.
Survey Demografi dan Kesehatan Indonesia (SDKI).2012. Laporan Pendahuluan.

Badan Pusat Statistik, Badan Kependudukan dan Keluarga Berencana Nasional, Kementerian Kesehatan, MEASURE DHS ICF International.

Notoatmodjo, S., 2012. Promosi Kesehatan dan Perilaku Ke-sehatan. Rineka Cipta. Jakarta.

Parwieningrum, E., 2009. Gender dalam KB/KR. Pusat Pelatihan Gender dan Peningkatan Kualitas Perempuan. Badan Koordinasi Keluarga Berencana Nasional.

Satyavada, A., and Adamchak, D.J. 2000. Determinants of Current Use of Contraception and Children Ever Born in Nepal. Social Biology.

Suliyanto, 2005. Analisis Data Dalam Aplikasi Pemasaran. Ghalia Indonesia, Bogor.

Suprihastuti, D.R, 2000. Pengambilan Keputusan Penggunaan Alat Kontrasepsi Pria di Indonesia, Analisis Hasil SDKI 1997, Jakarta

Widodo, A, Siswanto A.W, dan Yayi S.P, 2004. Pengetahuan dan Sikap Pasangan Suami Istri Mengenai Masalah Kesehatan Reproduksi Perempuan Hu-bungannya dengan Partisipasi Pria dalam KB, Sains Kesehatan, UGM, Yogyakarta 